\title{
Concept formation of ambience for labor and normal institutionalized delivery
}

\author{
Formação do conceito ambiência para trabalho de parto e parto normal institucionalizado
}

Elaboración del concepto de ambiencia para el trabajo de parto y el parto normal institucionalizado

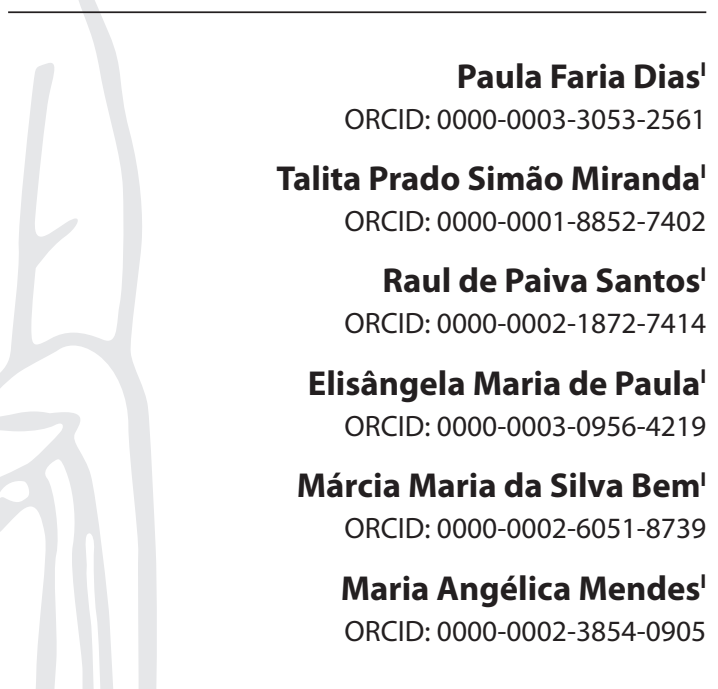

'Universidade Federal de Alfenas. Alfenas, Minas Gerais, Brazil.

How to cite this article: Dias PF, Miranda TPS, Santos RP, Paula EM, Bem MMS, Mendes MA. Concept formation of ambience for labor and normal institutionalized delivery. Rev Bras Enferm. 2019;72(Suppl 3):348-59. doi: http://dx.doi.org/10.1590/0034-7167-2018-0698

\section{Corresponding Author:}

Paula Faria Dias

E-mail: paulafariadias@hotmail.com

Submission: 09-07-2018

Approval: 06-17-2019

\begin{abstract}
Objective: to develop the concept ambience for labor and normal institutionalized delivery, identifying in the literature its antecedent, defining attributes and the consequent. Method: the method used was the analysis of literature, corresponding to the first stage of the qualitative method of concept analysis. The theoretical operation was performed in the databases CINAHL COCHRANE, LILACS, PsycINFO, and PubMed. Results: aspects of the parturient woman and the qualification of the physical and social space are presented as the antecedent. The defining attributes outline the assistance interaction process with NonInvasive Technologies. As the consequent, we highlight the outcome for normal delivery, pain relief and comfort, woman satisfaction and well-being. Final considerations: the analysis of the antecedent, defining attributes and the consequent allowed the elaboration of an unprecedent theoretical proposition of this concept.
\end{abstract}

Descriptors: Labor; Natural Childbirth; Hospitals; Concept Formation; Hospital, Maternity.

\section{RESUMO}

Objetivo: elaborar o conceito ambiência para trabalho de parto e parto normal institucionalizado, identificando na literatura seus antecedentes, atributos definidores e consequentes. Método: empregou-se o método da análise crítica da literatura, correspondendo à primeira etapa da metodologia qualitativa de análise de conceito. A exploração teórica foi realizada nas bases de dados CINAHL, COCHRANE, LILACS, PsycINFO e PubMed. Resultados: elementos referentes à parturiente e à qualificação do espaço físico e social são apresentados como antecedentes. Os atributos definidores delineiam o processo de interação assistencial com o uso das Tecnologias Não Invasivas. Como consequentes, destacam-se desfecho para o parto normal, alívio e conforto da dor, satisfação e bem-estar da parturiente. Considerações finais: a análise dos antecedentes, atributos definidores e consequentes permitiu elaborar uma proposição teórica inédita desse conceito.

Descritores: Trabalho de Parto; Parto Normal; Hospitais; Formação de Conceito; Maternidades.

\section{RESUMEN}

Objetivo: elaborar el concepto ambiencia para el trabajo de parto y el parto normal institucionalizado, identificando en la literatura sus antecedentes, sus atributos definidores y consecuentes. Método: se utilizó el método de análisis crítico de la literatura, que corresponde al primer paso de la metodología cualitativa del análisis de concepto. Se hizo una búsqueda teórica en las bases de datos CINAHL, COCHRANE, LILACS, PsycINFO y PubMed. Resultados: los elementos relativos a la parturienta y a la calificación del espacio físico y social se presentan como antecedentes. Los atributos definidores delimitan el proceso de interacción de la atención con el uso de las tecnologías no invasivas. Ya de los consecuentes, se destacan el resultado del parto normal, el alivio del dolor y comodidad, la satisfacción y el bienestar de la parturienta. Consideraciones finales: el análisis de los antecedentes, atributos definidores y consecuentes permitieron elaborar una propuesta teórica inédita de este concepto.

Descriptores: Trabajo de Parto, Parto Normal, Hospitales, Formación de Concepto, Maternidades. 


\section{INTRODUCTION}

This study highlights the concept of ambience for labor and normal delivery; given its significant influence on the quality of the care provided to mother and child. Ambience in healthcare is characterized by a set of actions that comprise the physical, social/professional space and interpersonal relationships; these integrated actions build a health project focused on a welcoming, problem-solving and human care ${ }^{(1)}$. Fifteen years ago, in Brazil, the concept of ambience emerged as a guideline of the National Humanization Policy ${ }^{(2)}$, providing for the construction of collective processes in health promotion. These processes go beyond the physical and functional organization because they contribute to the qualification of the labor system as a strategy of good practice, especially the humanized care delivery ${ }^{(3)}$.

Recently, Brazilian institutions of childbirth assistance have gathered efforts to establish the ambience, aiming to ensure the safety of mother-child and companion, their welcoming reception and comfort, in addition to the preservation of privacy ${ }^{(3)}$. Thus, interventions have been implemented, although timidly, as the protagonism of women and respect for their needs; the presence of a companion; the stimulus to drive and ambulation; freedom of choice of position during the pre-delivery and delivery; soft food intake; and the termination of traditional practices such as amniotomy and routine episiotomy. Also, Non-Invasive Technologies (NIT) have been implemented, among them the Swiss ball, lumbar and perineal massage, aromatherapy, music therapy, and hydrotherapy(3).

Although the term ambience is engaged in the usual way, the new concept still prevails, which involves an apparent lack of reality about its bases and consequently its real significance in relation to the birth. Moreover, there is a tendency to correlate ambience with environment by restricting the concept to the physical structures at the expense of professional and personal relationships. Thus, discussions between health managers, professionals and researchers have provoked with the need to better understand this concept and try to incorporate it to the obstetric practice.

The concept can be understood as "cognitive representations" of a perceived reality, from direct or indirect experience, which may be based on situations, events or actual behaviors ${ }^{(4)}$. To understand a concept, it is necessary to know its constituent elements, i.e. its antecedent, its defining attributes and consequences ${ }^{(5)}$. defining attributes are words and/or phrases used to define the properties that make up the concept of interest, differentiating it from other similar concepts or the like ${ }^{(6)}$. The antecedent and concept of the consequent are described by situations, events or incidents that happen before and after the study phenomenon.

As we did not find in the literature any study that specifically addressed the concept of ambience in obstetrics, there is a pressing need to identify its attributes through studies on clarification and conceptual development ${ }^{(7)}$. It is noteworthy that in this study the formation of the concept of ambience is limited to care during the pre-delivery and delivery period, composing, in in this case, the normal institutionalized delivery process, whether in a maternity or in a birth center.

\section{OBJECTIVE}

To develop the concept of ambience for labor and normal institutionalized delivery, identifying in the literature its antecedent, defining attributes and consequences.

\section{METHOD}

A qualitative method of concept analysis was used ${ }^{(7)}$. This analysis intends to equip the research for development, design, comparison, clarification, correction or identification of a concept and consists of three steps: the identification of indicative concept attributes; verification of these attributes; and, finally, the manifestation of the concept $t^{(4,7)}$. This study corresponds to the first step of the qualitative methodology of concept analysis, which is employed in the method of critical analysis of literature ${ }^{(7)}$. This method allows us to investigate different perceptions of the concept in question, contexts in which it is being used and information about its explicit and implicit attributes, helping to assess its logical coherence ${ }^{(8)}$ and know the implications of its adoption in practice. In critical review, the attributes may be obtained by different ways, such as by the use of literature as data source, by participant observation, or even by interviews ${ }^{(4)}$. In this study they were identified in the scientific literature.

\section{Sources of information and research}

The theoretical exploration was carried out in January and February 2018. Figure 1 shows the descriptors and strategies applied, according to databases, as well as the process of exploration and the selection of the references ${ }^{(9)}$.

\section{Eligibility criteria}

Publications that presented possible defining elements of the concept of ambience and that evidenced interactions in labor and normal institutionalized delivery were included. Moreover, studies published in full text in Portuguese, English or Spanish, as of the year 2000, were selected. This date is justified by approaching the year of the creation of the Prenatal and Birth Humanization Program (PHPN) ${ }^{(10)}$, which underlies the premise of humanization in childbirth and hence ambience for labor and delivery.

The references that did not include the object of this study were excluded. In general, they were related to surgical delivery, the use of medications, specific diseases, prenatal, noninstitutionalized delivery, private techniques or procedures in a professional category, the late and remote puerperium, abortion, and to newborns after hospital discharge. Also, the references that were not a scientific study or showed inconclusive results were excluded, as well as those that were duplicated in the database (Figure 1) ${ }^{(9)}$.

\section{Process of review and selection of studies in databases}

The process was conducted by the authors, with most of them being nurses and three being specialists in obstetrics. It began with the reading of the title and summary of references in order to 

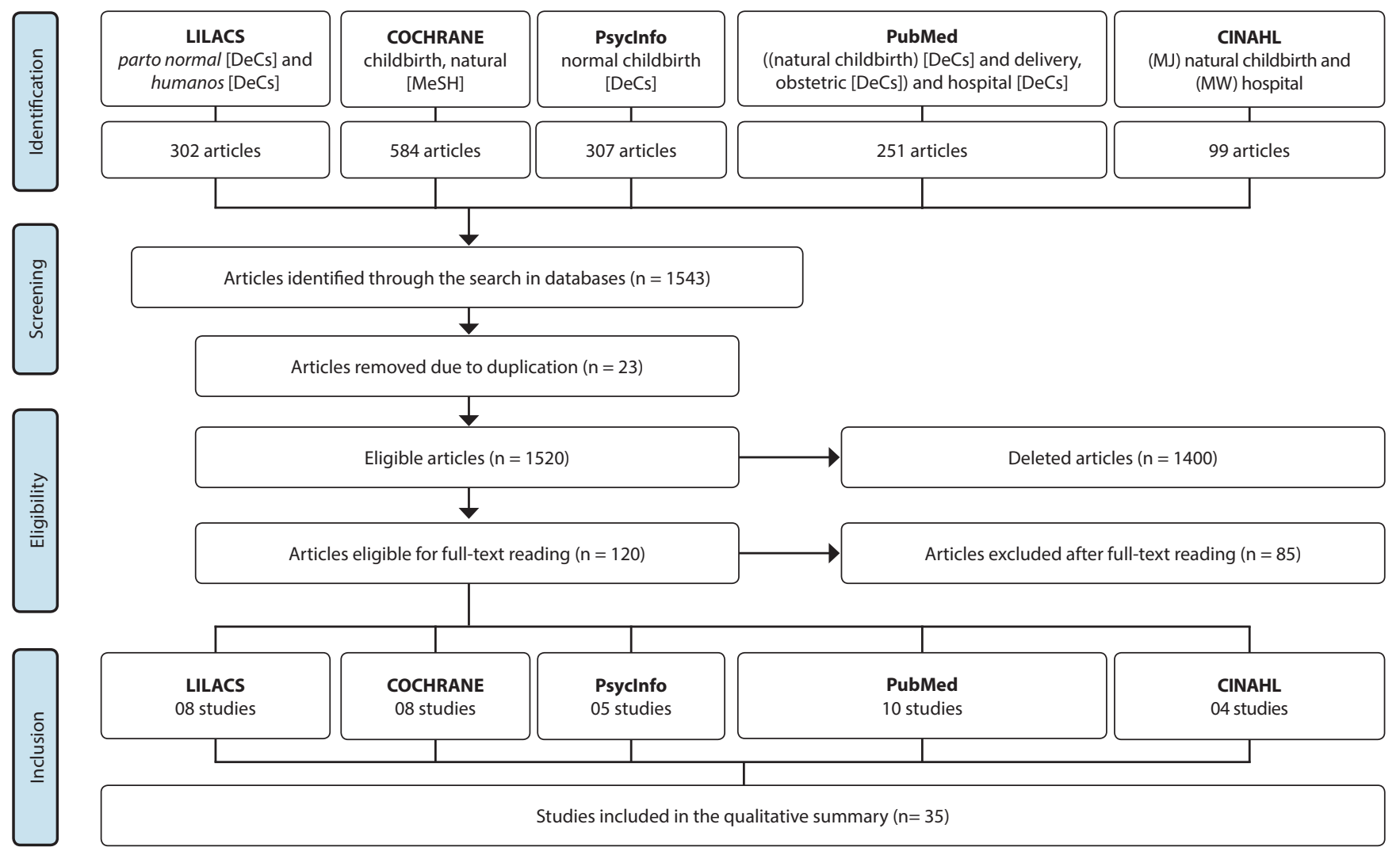

584 articles

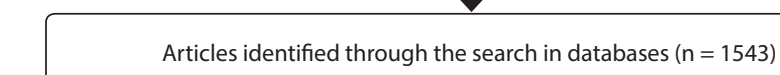

obstetric [DeCs]) and
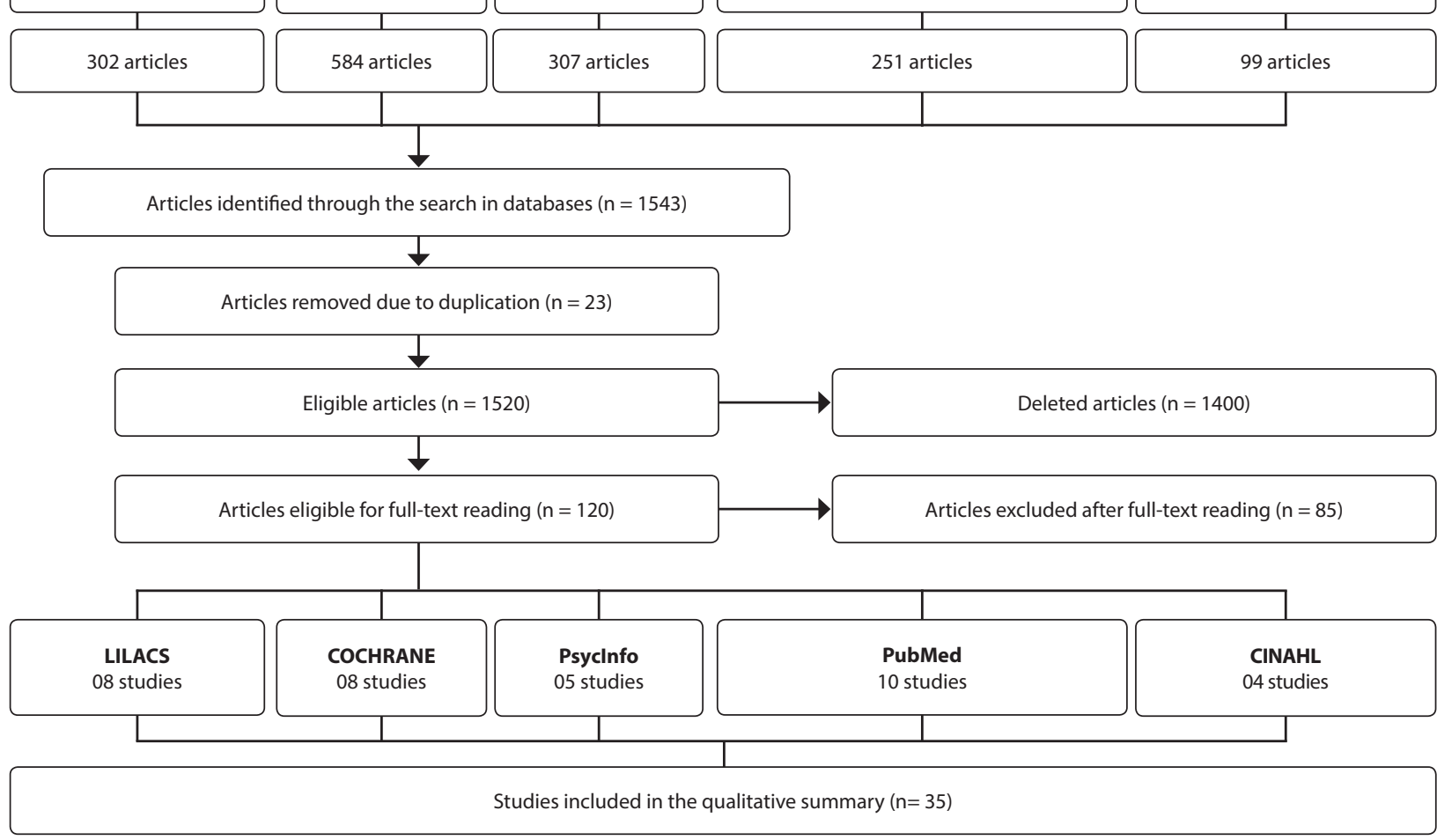

Source: Moher D et al. ${ }^{(10)}$

Figure 1 - PRISMA flow chart of the research in Databases, 2018

select those relevant to the objective of the study. In the absence of summary or when it did not allow such a definition, the publication was maintained for the next phase of full-text reading. These were read in full and analytically, with the purpose of identifying those who bring possible contributions to the study, that is, present elements of the concept of ambience for labor and normal institutionalized delivery; which may be an antecedent, a defining attribute or a consequent. Thus, new screening occurred, which determined the references to be analyzed (Figure 1) ${ }^{(9)}$.

\section{Data extraction}

The data extraction was performed by the authors and nursemidwives and began with the full-text reading and critical analysis of selected studies. Initially, information was extracted to characterize the studies (Chart 1). Then they highlighted parts of texts that could provide elements to the concept of ambience for labor and normal institutionalized delivery. These small pieces were analyzed by considering their arguments and their context, and they received a representative name of that content, constituting a code. To facilitate the recovery of information and codes, Microsoft Excel 2010 was employed. Next, we identified to which element the code belonged: whether it were the antecedents, defining attributes or the consequent. In the event of inaccuracies, it was required greater reflection of nurse-midwives to then define which attribute it was, making some changes to its definitive identification. In addition, an element may be present at the same time as antecedent, defining attribute or consequent ${ }^{(6)}$.

\section{Data analysis}

Qualitative methodologies for concept analysis has as main purpose the organization and consolidation of data into categories ${ }^{(7)}$. Also, the categorical classification is intended to identify the defining attributes, with the antecedent and the consequent ${ }^{(7)}$, in this case, of ambience for labor and normal institutionalized delivery. To this end, the analysis performed to identify the attributes and categories of the construction was based, more specifically, on the broad concept of ambience ${ }^{(3)}$ and on the premises of PHPN ${ }^{(10)}$. The review has been achieved through the constant comparative process, in order to identify conceptual boundaries of ambience for labor and normal delivery, that is, characteristics that distinguish it from other concepts, such as humanization or welcoming care, making the study concept more clearly defined ${ }^{(7)}$. Thus, the codes were compared and clustered depending on the similarity of their meanings, and, inductively, names were established to the generated clusters. From the evaluation and constant comparison of the similarities and variations between clusters, categories and subcategories of analysis were created $^{(7)}$. As the codes were arranged in the antecedent, defining attributes, and consequent, the categories formed preserved this organization. The contents of newly formed categories were compared to verify their suitability and relevancy. And the categories that referred to the same attribute of ambience were merged and reorganized to improve their creation. Finally, the categories were named based on the interpretation of the meanings of their attributes, applying techniques of abstraction and synthesis, seeking to accurately describe the contents 
of each category ${ }^{(7)}$. Sometimes, their names have been changed in the search for a representative denomination adjusted to the meaning of the attributes clustered when then became definitive.

\section{Methodological rigor}

In the step of data extraction and identification of the antecedent, defining attributes and the consequent, other professionals specialized in obstetric care were consulted when doubts and dilemmas raised. Also, the initial step of data analysis and creation of categories were carried out independently by the authors and nurse-midwives. Then they have together reached a consensus on the definition of the categories and submitted for the validation of a fourth nurse mid wife.

\section{RESULTS}

Initially, we present the results of the study selection process (Chart 1). Then we show the specific frames of the antecedent (Chart 2), defining attributes (Chart 3), and the consequent (Chart 4). As a result, we present the theoretical-conceptual proposition of ambience for labor and normal institutionalized delivery.

\section{Studies characteristics}

In theoretical exploration, 69 references were selected for the study. However, in this article, those of greater relevance and relevance to the concept of training were employed. Thus, the process of search and selection considered $35^{(11-45)}$ references, much of qualitative approach, seven clinical trials, among other methods, through which the attributes of the concept of ambience were identified for labor and normal institutionalized delivery. Table 1 shows the key characteristics of the studies.

Whereas the theoretical exploration did not include any studies that specifically address the ambience in the context of health or obstetrics, the selected publications present the elements of the concept of ambience for labor and normal institutionalized delivery, such as the element of NIT. Most ${ }^{(11-12,14-25,27-28,30,32-35,37,40-44)}$ publications consist of empirical studies, confirming the property of the antecedent, defining attributes and the consequent analyzed. Regarding the country of origin of studies, almost half of them were conducted in America ${ }^{(12,14,16-17,20,22,26-27,30-31,34,36-38,41,43,45)}$, more specifically in Bra$\mathrm{zil}^{(12,16-17,20,22,27,34,36-37,41,43)}$, agreeing with the relevance of this study of concept formation.

Chart 1 - Characteristics of the study publications, 2018

\begin{tabular}{|c|c|c|c|c|}
\hline Reference & Year/Country & $\begin{array}{l}\text { Design/ } \\
\text { number of patients }\end{array}$ & Intervention/Focus & Outcome/Conclusion \\
\hline $\begin{array}{l}\text { Larkin, Begley, Devane, } \\
\qquad 2017^{(11)}\end{array}$ & $\begin{array}{l}2017 \\
\text { Ireland }\end{array}$ & $\begin{array}{l}\text { Cross Quantitative } \\
\text { Approach } n=531\end{array}$ & $\begin{array}{l}\text { Most significant element to } \\
\text { women in labor }\end{array}$ & Pain relief \\
\hline $\begin{array}{l}\text { Kologeski, Strapasson, } \\
\text { Schneider, Renosto, } \\
2017^{(12)}\end{array}$ & $\begin{array}{l}2017 \\
\text { Brazil }\end{array}$ & $\begin{array}{l}\text { Qualitative Content } \\
\text { Analysis Approach } \\
\qquad \mathrm{n}=15\end{array}$ & $\begin{array}{l}\text { Professional's perception of } \\
\text { skin contact }\end{array}$ & $\begin{array}{l}\text { Staff has difficulties in adhering to the } \\
\text { practice }\end{array}$ \\
\hline $\begin{array}{l}\text { Gupta, Sood, Hofmeyr, } \\
\text { Vogel, 2017 }\end{array}$ & $\begin{array}{c}2017 \\
\text { United Kingdom }\end{array}$ & $\begin{array}{c}\text { Review } \\
\mathrm{n}=30\end{array}$ & $\begin{array}{l}\text { Labor } \\
\text { position }\end{array}$ & Upright position reduced the labor length \\
\hline $\begin{array}{l}\text { Happel-Parkins, Azim, } \\
\qquad 2016^{(14)}\end{array}$ & $\begin{array}{l}2016 \\
\text { USA }\end{array}$ & $\begin{array}{l}\text { Thematic Qualitative } \\
\text { Analysis Approach } \\
\qquad n=6\end{array}$ & $\begin{array}{l}\text { Primigravida experience with } \\
\text { normal delivery }\end{array}$ & Often their basic rights were disregarded \\
\hline $\begin{array}{c}\text { Aune, Torvik, Selboe, } \\
\text { Skogås, Persen, Dahlberg, } \\
2015^{(15)}\end{array}$ & $\begin{array}{l}2015 \\
\text { Norway }\end{array}$ & $\begin{array}{l}\text { Qualitative Approach/ } \\
\text { Systematic Texts } \\
\text { Condensation } \\
n=12\end{array}$ & $\begin{array}{c}\text { Factors that influence the } \\
\text { woman's positive experience } \\
\text { of normal delivery }\end{array}$ & Safe environment and emotional strength \\
\hline $\begin{array}{l}\text { Borem, Ferreira, Silva, Valério } \\
\text { Júnior, Orlanda, } 2015^{(16)}\end{array}$ & $\begin{array}{l}2015 \\
\text { Brazil }\end{array}$ & $\begin{array}{l}\text { Descriptive Study } \\
\qquad n=1449\end{array}$ & $\begin{array}{c}\text { Redesign of the Birth Model } \\
\text { of Care }\end{array}$ & $\begin{array}{l}\text { Reduction in the percentage of caesarean } \\
\text { sections }\end{array}$ \\
\hline $\begin{array}{l}\text { Côrtes, Santos, Caroci, } \\
\text { Oliveira, Oliveira, Riesco, } \\
2015^{(17)}\end{array}$ & $\begin{array}{l}2015 \\
\text { Brazil }\end{array}$ & $\begin{array}{l}\text { Quasi-experimental } \\
\qquad n=50\end{array}$ & $\begin{array}{l}\text { Implementation of best } \\
\text { practices in normal delivery }\end{array}$ & Positive impact \\
\hline $\begin{array}{l}\text { Coxon, Sandall, Fulop, } \\
\qquad 2015^{(18)}\end{array}$ & $\begin{array}{c}2015 \\
\text { United Kingdom }\end{array}$ & $\begin{array}{l}\text { Qualitative Approach } \\
\qquad \mathrm{n}=41\end{array}$ & $\begin{array}{l}\text { Influence of the current } \\
\text { labor on planning the next } \\
\text { pregnancy }\end{array}$ & $\begin{array}{c}\text { Current experience influences the choice } \\
\text { of the next delivery location - Hospital or } \\
\text { Birth Center }\end{array}$ \\
\hline $\begin{array}{l}\text { Hajian, Shariati, Mirzaii } \\
\text { Najmabadi, Yunesian, } \\
\text { Ajami, 2015(19) }\end{array}$ & $\begin{array}{l}2015 \\
\text { Iran }\end{array}$ & $\begin{array}{l}\text { Quali/Quanti Approach } \\
\qquad \mathrm{n}=290\end{array}$ & $\begin{array}{l}\text { Cultural influence on the } \\
\text { intention by normal delivery }\end{array}$ & $\begin{array}{c}\text { Confident mothers are more likely to } \\
\text { have normal delivery }\end{array}$ \\
\hline $\begin{array}{l}\text { Scarton, Prates, Wilhelm, } \\
\text { Silva, Possati, Ilha, } 2015^{(20)}\end{array}$ & $\begin{array}{l}2015 \\
\text { Brazil }\end{array}$ & $\begin{array}{l}\text { Qualitative Description } \\
\qquad \begin{array}{l}\text { Approach } \\
\mathrm{n}=10\end{array}\end{array}$ & $\begin{array}{l}\text { Experience of primiparous in } \\
\text { normal delivery }\end{array}$ & $\begin{array}{c}\text { The care reflects on the coping } \\
\text { experience and delivery }\end{array}$ \\
\hline $\begin{array}{c}\text { Serçekuş, Egelioglu Cetisli, } \\
\text { İnci, 2015 }\end{array}$ & $\begin{array}{l}2015 \\
\text { Turkey }\end{array}$ & $\begin{array}{l}\text { Cross-sectional study } \\
\qquad \mathrm{n}=162\end{array}$ & $\begin{array}{l}\text { Preference on the type of } \\
\text { birth }\end{array}$ & $\begin{array}{l}90.8 \% \text { of women and } 92 \% \text { of their } \\
\text { partners chose normal delivery }\end{array}$ \\
\hline
\end{tabular}


Chart 1

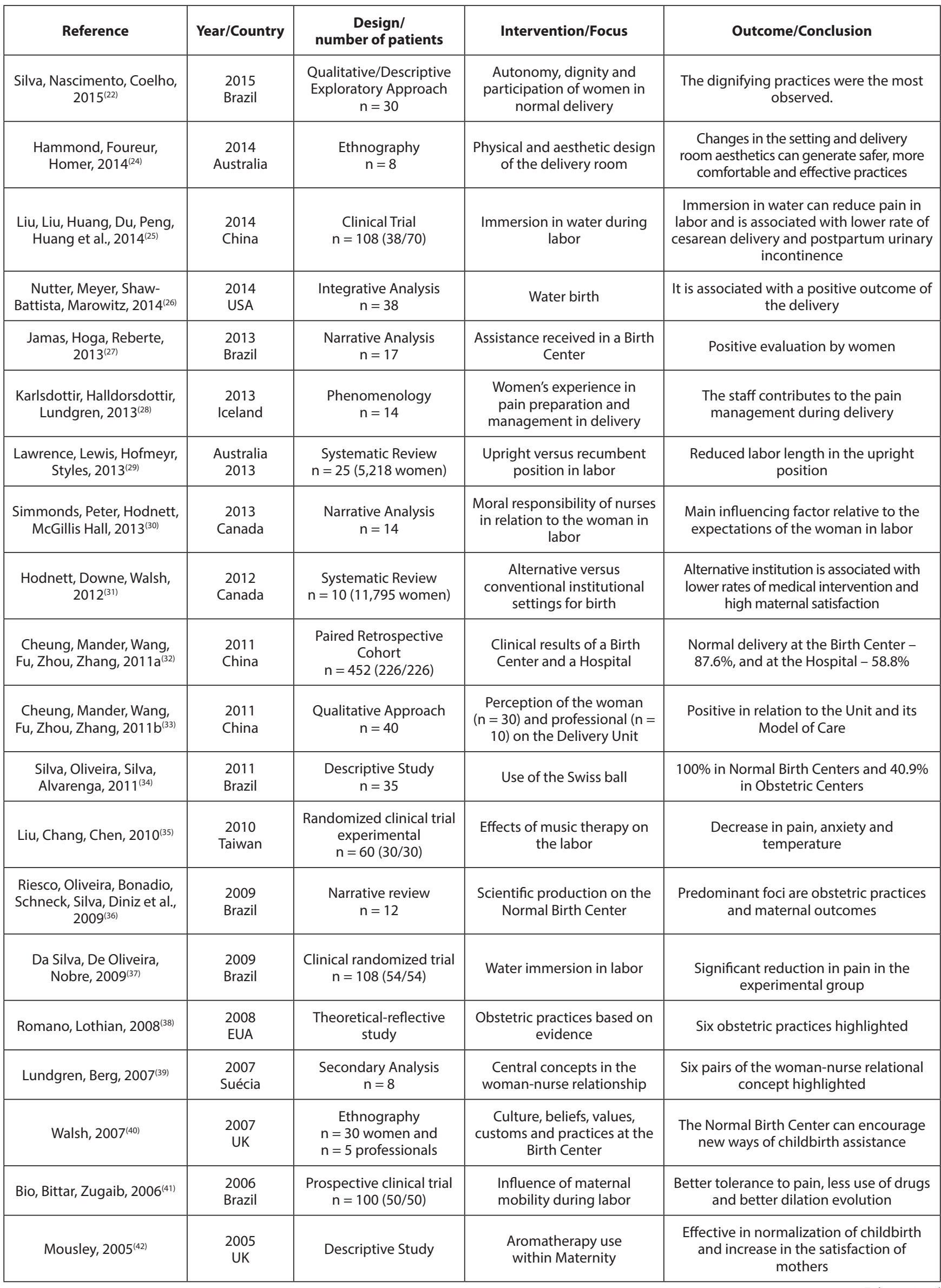


Chart 1 (concluded)

\begin{tabular}{|c|c|c|c|c|}
\hline Reference & Year/Country & $\begin{array}{l}\text { Design/ } \\
\text { number of patients }\end{array}$ & Intervention/Focus & Outcome/Conclusion \\
\hline Hoga, $2004^{(43)}$ & $\begin{array}{l}2004 \\
\text { Brazil }\end{array}$ & $\begin{array}{l}\text { Thematic Oral History } \\
\qquad n=6\end{array}$ & $\begin{array}{l}\text { Motivation of nurse insertion } \\
\text { at the Birth Center }\end{array}$ & $\begin{array}{l}\text { Dissatisfaction with the Biomedical } \\
\text { Model, with the hospital interventionist } \\
\text { character and the desire to transform }\end{array}$ \\
\hline Yildirim, Sahin, 2004 ${ }^{(44)}$ & $\begin{array}{l}2004 \\
\text { Turkey }\end{array}$ & $\begin{array}{l}\text { Clinical trial } \\
n=40(20 / 20)\end{array}$ & $\begin{array}{l}\text { Effects of the breathing and } \\
\text { massage technique on labor }\end{array}$ & Effective in reducing pain \\
\hline Lauzon, Hodnett, $2001^{(45)}$ & $\begin{array}{c}2001 \\
\text { Canada }\end{array}$ & $\begin{array}{l}\text { Systematic Review } \\
n=209(105 / 104)\end{array}$ & $\begin{array}{l}\text { Effects of the Labor } \\
\text { Assessment Program }\end{array}$ & $\begin{array}{l}\text { Evidence of benefits to women in labor } \\
\text { with term pregnancy }\end{array}$ \\
\hline
\end{tabular}

\section{Summary of categories and subcategories}

The critical analysis of the literature ${ }^{(4,7)}$ enabled the creation of categories of analysis that name elements of the concept of ambience for labor and normal institutionalized delivery, namely the antecedent, defining attributes and the consequent. To better explain the elements of the categories, in turn, they can be divided into subcategories. Briefly, categories and subcategories are presented below.

\section{Antecedent of the concept of ambience for labor and normal institutionalized delivery}

These are elements that precede the establishment of the ambience and permeate the social context of its application ${ }^{(6)}$, are organized into two categories (Chart 2):

- Meaning ascribed to motherhood by the women in labor added to the self-esteem and confidence in their body in the childbirth process and in health professionals, and the preference and willingness to surrender to the labor and delivery with good expectations for the institution;

- Qualified physical and social space.

The category "Qualified physical and social space" has four subcategories:

- Qualified physical space;

- Qualified staff with informative experience, clinical autonomy, critical thinking, emotional self-control, and contribution of each professional;

- Close relationship, trust, and therapeutic and equal affection with the mother, based on the recognition of her uniqueness, her capacity for normal delivery and stimulating the protagonism in delivery;

- Teamwork process based on confidence in the clinical competence of professionals to ensure the safety of the mother, the Admission Assessment Program, the possibility of spontaneous onset of labor, soft food intake, the choice of companion and labor position and delivery for the woman in labor.

Considering that assistance to labor and delivery will be focused on the woman in labor and that she will be the protagonist, as the antecedent, it is imperative to promote self-esteem and self-confidence through encouragement and team support, raising awareness about their ability for delivery ${ }^{(30,39)}$. Another antecedent of ambience is the preference of the mother for normal delivery added to her good expectations and the family's regarding the institution ${ }^{(40)}$. Also, as the antecedent, we highlight the qualification not only of the physical space, but also of the social institution; comprising the local and the professionals in the first call to the woman in labor until the completion of the delivery process. In particular, the physical and functional settings of the institution must provide resources to carry out the $\mathrm{NIT}^{(34,37)}$.

The antecedent to the concept of ambience describes specific aspects of the mother and the environment; including interpersonal relationships and the teamwork process. However, we observed that the antecedent does not follow a logical sequence of continuity, but, together, they are foundational elements of ambience for labor and delivery.

Chart 2 - Categories and subcategories of analysis of the antecedent for the concept of ambience for labor and normal institutionalized delivery, 2018

\section{ANTECEDENT OF THE CONCEPT OF AMBIENCE FOR LABOR AND NORMAL INSTITUTIONALIZED DELIVERY}

Meaning ascribed to motherhood by the women in labor plus the self-esteem and confidence in their body in the childbirth process and in health professionals, and the preference and willingness to surrender to the labor and delivery with good expectations regarding the institution

Meaning ascribed to motherhood ${ }^{(39)}$; High self-esteem ${ }^{(30)}$; Self-confidence ${ }^{(15,30,39)}$; Trust in your body and in the delivery process ${ }^{(14,15,28)}$; Trust in health professionals ${ }^{(11,19,39)}$; Preference for normal delivery ${ }^{(21,31)}$; Willingness to surrender to the labor and delivery ${ }^{(39)}$; Good expectations regarding the institution ${ }^{(40)}$.

Qualified physical and social space

\begin{tabular}{|c|c|}
\hline Subcategories & Codes and references \\
\hline Qualified physical space & $\begin{array}{l}\text { Propitious institutional physical setting }{ }^{(22,24,31)} \text {; Resources for Non-Invasive Technologies }{ }^{(22,34,37)} \text {; } \\
\text { Relaxing environment }{ }^{(32)} \text {. }\end{array}$ \\
\hline $\begin{array}{l}\text { Qualified staff with informative experience, clinical } \\
\text { autonomy, critical thinking, emotional self-control } \\
\text { and contribution of each professional }\end{array}$ & $\begin{array}{l}\text { Qualified staff( } 11,43) \text {; Experience informed by the staff(39); Appropriation of clinical autonomy }{ }^{(23)} \text {; } \\
\text { Critical thinking }{ }^{(39)} \text {; Emotional self-control }{ }^{(30)} \text {; Contribution as a professional }{ }^{(33,39)} \text {; Belief in } \\
\text { assistance to normal delivery }{ }^{(23,39)} \text {. }\end{array}$ \\
\hline
\end{tabular}




\begin{tabular}{|c|c|}
\hline Subcategories & Codes and references \\
\hline $\begin{array}{l}\text { Close relationship, trust, therapeutic and equal } \\
\text { affection with the mother, based on the recognition } \\
\text { of her uniqueness, her capacity for normal delivery } \\
\text { and stimulating the protagonism in delivery; }\end{array}$ & $\begin{array}{l}\text { Recognition of uniqueness }{ }^{(39)} \text {; Belief in the capacity of the mother }{ }^{(39)} \text {; } \text { close relationship }^{(27,39)} \text {; } \\
\text { Trust relationship }{ }^{(18,39)} \text {; Equal relationship }{ }^{(39)} \text {; Therapeutic Affective Relationship }{ }^{(40)} \text {. }\end{array}$ \\
\hline $\begin{array}{l}\text { Teamwork process based on confidence in the } \\
\text { clinical competence of professionals to ensure the } \\
\text { safety of the mother, the Admission Assessment } \\
\text { Program, the possibility of spontaneous onset of } \\
\text { labor, soft food intake, the choice of companion } \\
\text { and labor position and delivery for the woman in } \\
\text { labor. }\end{array}$ & $\begin{array}{l}\text { Confidence in the clinical competence among professionals }{ }^{(30)} ; \text { Team work }^{(23,30)} \text {; Presentation } \\
\text { of the mother to the institution of choice for labor and delivery }{ }^{(40)} \text {; Safety of the mother }{ }^{(37)} \text {; } \\
\text { Guarantee of the possibility of spontaneous onset of labor }{ }^{(38)} \text {; Admission Assessment } \\
\text { Program }{ }^{(15,45)} \text {; Guarantee of choice of the mother's companion }{ }^{(14)} \text {; Guarantee of the choice } \\
\text { of the mother on the intake of soft foods and liquids }{ }^{(36)} \text {; Guidelines on benefits of upright } \\
\text { positions during labor and delivery }{ }^{(29)} \text {; Guarantee of the choice of childbirth position }{ }^{(13)} ; \text { Staff } \\
\text { flexibility regarding standards and institutional routines }{ }^{(27)} \text {. }\end{array}$ \\
\hline
\end{tabular}

\section{Defining attributes of the concept of ambience for labor and normal institutionalized delivery}

Attributes refer to defining characteristics, whether explicit or implicit, related to a particular concept itself(6), delineating its peculiarities. The peculiarities of the concept of ambience are set into two categories (Chart 3 ) restricted to the assistance interaction process as a whole and to the use of NIT, which are:

- Assistance process focused on the woman in labor triggered by the empowerment and protagonism of labor and delivery, sequenced by clinical assessment and interventions guided by the evidence of changes in the natural dynamics of labor and delivery, the judicious use of oxytocin, the amniotomy and episiotomy, and early promotion of skin contact;
- Use of NIT as presence and continuous support companion, friendly environment for relaxation, acupuncture, walking, bathing, Swiss ball, massage, compresses, ventilatory exercises, soft food intake and freedom of labor and delivery position.

Such attributes are in the categories and subcategories of analysis with references. Ambience for labor and normal institutionalized delivery is established from a collective interactional process involving woman in labor, staff and companion. Considering the centered care in women in labor, the ambience has as its central attribute the empowerment of the woman in labor and the protagonism of labor and delivery ${ }^{(30,39)}$. Given the scientific evidence on the avoidance of morbidity for the mother and the fetus, the judicious use of oxytocin infusion, the amniotomy and episiotomy ${ }^{(36)}$ stands as a defining attribute of interventions

Chart 3 - Categories and subcategories of analysis of defining attributes for the concept of ambience for labor and normal institutionalized delivery, 2018

\section{DEFINING ATTRIBUTES OF THE CONCEPT OF AMBIENCE FOR LABORAND NORMAL INSTITUTIONALIZED DELIVERY}

Assistance process focused on the woman in labor triggered by the empowerment and protagonism of labor and delivery, sequenced by clinical assessment and interventions guided by the evidence of changes in the natural dynamics of labor and delivery, the judicious use of oxytocin, the amniotomy and episiotomy, and early promotion of skin contact;

Assistance focused on the woman with continued attention ${ }^{(11,23,39)}$; Awareness of the mother of continued care, focused on her ${ }^{(39)}$; Resolutive welcoming ${ }^{(20,22,27)}$; Clinical assessment ${ }^{(23,40,45)}$; Prioritization of emergency calls ${ }^{(27)}$; Guidance on labor and delivery ${ }^{(20,27,30,39)}$; Empowerment to the protagonism of the mother for labor and delivery ${ }^{(11,18,22,39)}$; Active listening ${ }^{(39)}$; Interventions on the evidence of changes in the natural dynamics of the labor and delivery ${ }^{(38-39)}$; Judicious use of oxytocin infusion, the amniotomy and episiotomy ${ }^{(36)}$; Early promotion of skin contact ${ }^{(12)}$; Umbilical cord ligation ${ }^{(43)}$.

Use of NIT as presence and continuous support companion, relaxing environment, acupuncture, walking, bathing, Swiss ball, massage, compresses, ventilatory exercises, soft food intake and freedom of labor and delivery position.

\begin{tabular}{|l|l|}
\hline \multicolumn{1}{|c|}{ Subcategories } & \multicolumn{1}{c|}{ Codes and references } \\
\hline $\begin{array}{l}\text { Presence and continued support of the companion of } \\
\text { choice of the mother }\end{array}$ & $\begin{array}{l}\text { Presence of the companion of choice of the mother; Continued support of the } \\
\text { companion }^{(38)} .\end{array}$ \\
\hline Relaxation techniques & Relaxation techniques ${ }^{(32,35,42)}$. \\
\hline Walking & Walking ${ }^{(17,28,36)}$. \\
\hline Bath & Spraying and immersion baths ${ }^{(20,26-27,34,36)}$. \\
\hline Swiss ball & Use of the Swiss ball ${ }^{(34)}$. \\
\hline Massages & Massages ${ }^{(17,36)} \cdot$ \\
\hline Compresses & Hot or cold compresses ${ }^{(28)}$. \\
\hline Ventilatory exercises & Ventilatory exercises ${ }^{(44)}$. \\
\hline Soft food intake & Soft food during labor ${ }^{(36)}$. \\
\hline Freedom of labor and delivery position & Freedom of labor and delivery position ${ }^{(32,34,41)}$. \\
\hline
\end{tabular}


for ambience in the context of labor and delivery. And, as an intervention involving attribute the newborn, we highlight the practice of the early promotion of skin contact $^{(12)}$ and umbilical cord ligation $^{(43)}$.

In a peculiar way, NIT characterize the ambience, since they are procedures, techniques and knowledge aimed at retrieving the essence and autonomy of the mother during labor and delivery, mobilizing and enhancing her capacity as a major player in this process ${ }^{(46)}$. The use of NIT should be based on scientific evidence $^{(46)}$ due to their novelty in practice and to recognize the signs of each of them in accordance with the evolution of labor.

The defining attributes of the concept of ambience for labor and normal delivery show elements that define and delimit the concept; discussing the practice, on the use of NIT and the resources available to the physiological evolution of the labor and delivery.

\section{The consequent of the concept of ambience for labor and normal institutionalized delivery}

These are elements resulting from the application of the concept $^{(6)}$ of ambience for labor and normal institutionalized delivery. In turn, the consequent of the concept of ambience are shown in categories and subcategories composed of four categories (Chart 4), namely:

- Pain management, relief and comfort;

- Promotion of the natural evolution of labor with outcome for normal delivery;

- Avoidance of early admission to effectiveness in meeting the needs of the woman in labor, plus the delivery and protagonism in labor, satisfaction, well-being and safety, with feeling of relaxation and relief from anxiety;

Chart 4 - Categories and subcategories of analysis of the consequent for the concept of ambience for labor and normal institutionalized delivery, 2018

\section{CONSEQUENT OF THE CONCEPT OF AMBIENCE FOR LABOR AND NORMAL INSTITUTIONALIZED DELIVERY}

\section{Pain management, relief and comfort}

Self-confidence of the mother ${ }^{(15,39)}$; Acupuncture ${ }^{(28)}$; Music therapy ${ }^{(28,35)}$; Aromatherapy ${ }^{(42)}$; Mobility of the woman ${ }^{(28,33)}$; Shower ${ }^{(25-26)}$; Practice exercises ${ }^{(27,44)}$; Massage favoring pain management ${ }^{(28,36)}$; Swiss ball ${ }^{(27,34)}$; Compresses on the perineum ${ }^{(28)}$.

\section{Promotion of the natural evolution of labor with outcome for normal delivery}

Avoidance of routine interventions ${ }^{(38)}$; Labor and delivery in water ${ }^{(27)}$; Effective support of the companion ${ }^{(38)}$; Mobility of the woman ${ }^{(33,41)}$; Adoption of upright positions ${ }^{(13,38)}$; Use of the Swiss ball for greater permanence of the woman in the upright position ${ }^{(27,34)}$; Outcome of the normal delivery ${ }^{(11,16,31)}$

Avoidance of early admission with effectiveness in meeting the needs of the woman, plus delivery and protagonism in labor, satisfaction, well-being and safety with feeling of relaxation and relief from anxiety

Avoidance of early admission ${ }^{(45)}$; Effective meeting of the woman's needs ${ }^{(40)}$; Commitment to labor ${ }^{(39)}$.

\begin{tabular}{|c|c|}
\hline Subcategories & Codes and references \\
\hline Protagonism & Aromatherapy ${ }^{(42)}$; Favorable environment ${ }^{(24)}$. \\
\hline Satisfaction and well-being & 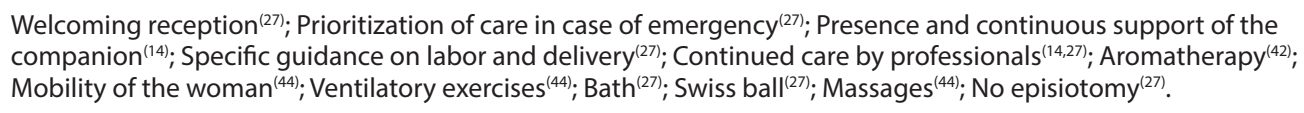 \\
\hline Safety & Presence of companion ${ }^{(27)}$; Continued care by professionals ${ }^{(27)}$; Staff and woman relationship ${ }^{(27)}$. \\
\hline Relaxation and relief from anxiety & Swiss ball ${ }^{(34)}$; Aromatherapy ${ }^{(42)}$; Music therapy ${ }^{(32,35) ;}$ Propitious environment ${ }^{(32)}$; Presence of the companion ${ }^{(27)}$. \\
\hline \multicolumn{2}{|c|}{$\begin{array}{l}\text { Reduced use of oxytocin, epidural analgesia and analgesics, with decrease in the occurrence of episiotomy and promotion of perineal } \\
\text { integrity, supported by therapeutic communication and staff satisfaction. }\end{array}$} \\
\hline Subcategories & Codes and references \\
\hline Therapeutic communication & Commitment ${ }^{(33)}$. \\
\hline Staff integration & Gratification $^{(43)}$; Satisfaction ${ }^{(24,43)}$; Facilitation of the staff performance ${ }^{(24)}$. \\
\hline Reduced use of oxytocin & Admission assessment of the woman ${ }^{(45)}$; Propitious institutional setting ${ }^{(31)}$. \\
\hline $\begin{array}{l}\text { Normal delivery without } \\
\text { epidural analgesia }\end{array}$ & $\begin{array}{l}\text { Admission assessment of the woman }{ }^{(45)} \text {; Propitious institutional setting }{ }^{(45)} \text {; Mobility of the woman }{ }^{(41)} \text {; Upright } \\
\text { position }^{(29) ;} \text { Labor and delivery in water }\end{array}$ \\
\hline Reduced use of analgesics & Mobility of the woman ${ }^{(41)}$. \\
\hline Promotion of perineal integrity & $\begin{array}{l}\text { Swiss Ball Effect assisting in the exercise of the perineal region }{ }^{(34)} \text {; Labor and delivery in water promoting the } \\
\text { perineal integrity }{ }^{(26)} \text {. }\end{array}$ \\
\hline $\begin{array}{l}\text { Decrease in the occurrence of } \\
\text { episiotomy }\end{array}$ & Propitious institutional setting ${ }^{(31)}$; Labor and delivery in water ${ }^{(26)} ;$ Upright position ${ }^{(13)}$. \\
\hline
\end{tabular}


- Reduced use of oxytocin, epidural analgesia and analgesics, with decrease in the occurrence of episiotomy and promotion of perineal integrity, supported by therapeutic communication and staff satisfaction.

Unlike the antecedent and defining attributes, in this study the concept of the consequent are based on its motivators, which are interrelated as a network, since a single element contributes to reaching different consequent. Thus, most of the elements that are constituted as the antecedent and attributes are validated as the consequent of the implementation of ambience in practice, in achieving the desired results.

Among the consequent, we highlight pain management, relief and comfort, and promotion of labor and normal delivery (Chart 4). The consequent pain management, relief and comfort is achieved through self-confidence of the mother regarding her body and her natural ability to give birth. Music therapy, acupuncture, aromatherapy, mobility of the woman and other interventions are recognized as technologies for relaxation and coping with pain and are mainly associated with the mother's protagonism in parturition and the restriction of the use of analgesics ${ }^{(28,33,42)}$.

Another important consequent of ambience is the promotion of the natural evolution of labor with outcome for normal delivery. The natural evolution of labor, the avoidance of unnecessary interventions is a fundamental element of the ambience, saving the natural physiological process of disruption and potential damage to the woman and the fetus ${ }^{(38)}$. Other elements favoring the promotion of labor, such as the effective support of the woman, free mobility ${ }^{(33,41)}$, adoption of upright positions ${ }^{(13,38)}$, and the use of Swiss ball(27,34).

\section{Theoretical proposition of the concept of ambience for labor and normal institutionalized delivery}

The analysis of the defining attributes, of the antecedent and the consequent of the concept of ambience, proposed by critical analysis of the literature ${ }^{(4,7)}$, enabled the development of a novel theoretical proposition of this concept, as shown:

Ambience for labor and normal institutionalized delivery is a complex biopsychosocial process based on collective interaction of the mother with her companion and the staff; focused on obstetric care, triggered by the reception and empowerment of the woman and the protagonism of labor and delivery, followed by clinical assessment and interventions guided by the evidence of changes in the natural dynamics of labor and delivery, the judicious use of oxytocin, the amniotomy, episiotomy and early promotion of skin contact integrated into the use of Non-Invasive Technologies, such as the presence and continued support, favorable environment for relaxation, walking, bathing, Swiss ball, massage, compresses, ventilatory exercises, soft food intake and freedom of position during labor and delivery. The antecedent is made up of the meaning attributed to motherhood by the woman plus the self-esteem and confidence in her body, the birthing process and health professionals, besides the preference and willingness to surrender to the labor and delivery with good expectations regarding the Institution. It includes qualified staff with informative experience, clinical autonomy, critical thinking, emotional selfcontrol and commitment of each professional in establishing close relationship, trust, therapy and equal affection with the woman based on the recognition of her uniqueness, capacity for normal delivery and in stimulating the birth protagonism with development of teamwork process based on confidence in the clinical competence of professionals to ensure the safety of the mother, the Admission Assessment Program, the possibility of spontaneous onset of labor, the choice of companion by the woman, soft food intake and freedom of position during labor and delivery, contextualized in a qualified physical space. Pain management, relief and comfort associated with the promotion of the natural evolution of labor with outcome for normal delivery, the avoidance of early admission with effectiveness in meeting the needs of the woman, plus her delivery and protagonism in labor, satisfaction, well-being and safety, with feeling of relaxation and relief from anxiety, in addition to the reduced use of oxytocin, epidural analgesia and analgesic with decrease in the occurrence of episiotomy and promotion of perineal integrity, based on therapeutic communication and staff satisfaction, are consequences of the application of the concept of ambience for labor and normal institutionalized delivery ${ }^{(47)}$.

\section{DISCUSSION}

The study identified in the literature, attributes of the concept of ambience for labor and normal institutionalized delivery. The first element includes antecedent conditions and actions that make up and set the ambience in care, such as the availability of material and human resources, knowledge and experience of professionals combined to interpersonal relationships. Given this context of establishment of ambience, health managers are also responsible for the establishment of a qualified delivery care environment, which should be suitable for the woman and her companion, as well as the staff( ${ }^{(1)}$. However, in the process of search and validation of antecedent elements, no data were found regarding the health managers in the promotion of ambience for labor and normal delivery, showing a gap in knowledge about the performance of such professionals in the qualification of the idealized obstetric care.

The defining attributes of the concept of ambience for labor and normal delivery characterize the institutionalized assistance focused on the woman, and at the same time, the same woman in labor is the protagonist of the assistance process. It includes the presence of the woman's companion of choice, the use of NIT for pain relief, soft food intake, freedom of position during labor, the promotion of skin to skin contact between mother and child, among others.

Finally, the consequent of the concept of ambience is related to the pain of labor and delivery, the outcome for normal delivery, and to the woman in labor. The consequent related to the woman's pain is related to its management and coping process. From this perspective, the great villain of the normal delivery is the pain of the contractions and the delivery itself, being the one responsible for women choosing operative delivery. The application of the concept of ambience in the obstetrical practice does not guarantee the fallacy of a "painless delivery," but it overcomes it. Therefore, the greatest contribution of the ambience is that it offers resources, explained by its antecedents and defining attributes, so that the parturient protagonist can face, manage, interact and relieve the pain in the labor and delivery process. 
For this reason alone, the ambience would be characterized as a justification for professionals and health managers to seek ways to make this practice feasible in obstetrics.

The consequent of the concept of ambience, promotion of the natural evolution of labor with outcome for normal delivery, is characterized as the main goal to be reached in establishing the ambience in obstetric care. This result can be achieved more easily with the assistance focused on the woman by the use of NIT, with appreciation of her desires and expectations, especially with her protagonism in labor and delivery. And the protagonism of the woman is characterized as the main element of the concept of ambience; since the scope of such an element, as the antecedent, as a defining attribute and consequent, enables the establishment of the ambience in labor and normal delivery.

The data obtained in the literature distinguish conceptual boundaries of the "environment for labor and normal institutionalized delivery" with the concept of "humanization of care for the woman and her companion." Although they are considered as distinct concepts, they are complementary to each other, since the ambience in the assistance to labor and delivery is directly related to the humanization of care for the woman ${ }^{(2)}$. The proposal of humanization in obstetric care reinforces the need to soften the routine at time of hospitalization, through a relation of exchange between the woman, her companion and health professionals ${ }^{(48)}$. Another conceptual issue of the ambience for labor and delivery refers to the welcoming reception of the woman and her companion, which is presented as a guideline of humanization in health ${ }^{(2)}$. In the concept of ambience, the affective and resolutive reception emerges as a defining attribute and as a consequent, being an element that promotes and, at the same time, is a result of the ambience in obstetric clinical practice.

\section{Limitations of the study}

One of them occurred in the beginning of the search in the scientific literature, since there were no specific descriptors that contemplated the ambience in health, being necessary to use descriptors that, as a whole, permeated the humanization and the ambience for labor and normal institutionalized delivery. Another limitation, which at the same time expresses the relevance of this study, was that no reference dealt directly with the ambience, nor did it specifically describe the attributes of the concept, be they antecedent, defining attributes or consequent; naturally due to the novelty of the concept of ambience in practice.

\section{Contributions to the field of nursing, health or public policies}

The identification of the concept of ambience through the attributes that define it and the factors that determine it and its consequent favor the concept of ambience in labor and delivery. In particular, the adoption of this concept aims to facilitate humanized health actions, through the valuation of the environment ${ }^{(49)}$. Thus, health professionals, including nurses, can improve the practice with the woman and the family. In addition, the content obtained in this study enables the labor and delivery assistance staff to be trained on interventions and activities that may be identified, assisting in the empowerment of the woman's protagonism in labor and delivery. Furthermore, the implementation of the ambience in the childbirth assistance service favors the person-centered approach and the integrality of care, enabling reflections on the model of women's health care ${ }^{(1)}$. Given the importance of this concept to humanized care, this study may provide a better identification and understanding of the strategies applied to the promotion of the ambience for labor and normal institutionalized delivery; offering a new proposal in the way of making and producing spaces that are more welcoming, more resolute and more humane in the field of obstetrics ${ }^{(1)}$.

\section{FINAL CONSIDERATIONS}

In addition to identifying attributes of the concept of ambiance for labor and normal institutionalized delivery, this study elaborated an unprecedented theoretical proposition for the concept, representing a theoretical-conceptual advance to the obstetric discipline.

The concept of ambience for labor and normal institutionalized delivery helps managers and nurse-midwives to leverage transformations and consequent evaluations, aiming at the excellence of care. Nevertheless, the concept of ambience supports and expands the obstetric practice, but it is considered more comprehensive than the concept, that is, the practice is much richer and complex than the possibility of talking about it, and results or the consequent achieved speak louder in practice. The theologian and philosopher of the 13th century, St. Thomas Aquinas (1225-1274), mentions the complex process that permeates the theory versus practice and observes the dynamics of the concept of structure when he says "The reason is the imperfection of intelligence, because the practice goes beyond the concept".

\section{FUNDING}

Fundação de Amparo à Pesquisa de Minas Gerais (FAPEMIG) Brazil. Process APQ 01273/16. Coordenação de Aperfeiçoamento de Pessoal de Nível Superior (CAPES).

\section{ERRATUM}

Article "Concept formation of ambience for labor and normal institutionalized delivery", with number of DOl: https://doi.org/10.1590/0034-7167-2018-0698, published in the journal Revista Brasileira de Enfermagem, 72(Suppl 3):348-59, on page 357:

Include after Final Considerations the information:

\section{FUNDING}

Fundação de Amparo à Pesquisa de Minas Gerais (FAPEMIG) - Brazil. Process APQ 01273/16. Coordenação de Aperfeiçoamento de Pessoal de Nível Superior (CAPES). 


\section{REFERENCES}

1. Ministério da Saúde (BR). Núcleo Técnico da Política Nacional de Humanização. Ambiência [Internet]. 2a ed. Brasília: Ministério da Saúde; 2010 [cited 2019 July 04]. Available from: http://bvsms.saude.gov.br/bvs/publicacoes/ambiencia_2ed.pdf

2. Ministério da Saúde (BR). Política Nacional de Humanização: PNH [Internet]. Brasília: Ministério da Saúde; 2013 [cited 2019 July 04]. Available from: http://bvsms.saude.gov.br/bvs/publicacoes/politica_nacional_humanizacao_pnh_folheto.pdf

3. Ministério da Saúde (BR). Orientações para elaboração de propostas da Rede Cegonha [Internet]. Brasília: Ministério da Saúde; 2012 [cited 2019 July 04]. Available from: http://www.saude.pi.gov.br/ckeditor_assets/attachments/141/MANUAL_DE_PROPOSTAS_REDE_CEGONHA.pdf

4. Morse JM. Exploring the theoretical basis of nursing using advanced techniques of concept analysis. ANS Adv Nurs Sci. 1995;17(3):31-46.

5. Cowles KV. Grief in a cultural context: expanding concept analysis beyond the professional literature. In: Rodgers BL, Knafl KA, editors. Concept development in nursing: foundations, techniques, and applications. Philadelphia: Saunders Company; 2000. p. 119-27.

6. Walker LO, Avant KC. Strategies for theory construction in nursing. New Jersey: Prentice Hall; 2005.

7. Morse JM, Hupcey JE, Mitcham C, Lenz ER. Concept analysis in nursing research: a critical appraisal. Sch Inq Nurs Pract. 1996;10(3):253-77.

8. Morse JM. Exploring pragmatic utility: concept analysis by critically appraising the literature. In: Rodgers BL, Knafl KA, editors. Concept development in nursing: foundations, techniques, and applications. Philadelphia: Saunders Company; 2000. p. 333-52.

9. Moher D, Liberati A, Tetzlaff J, Altman DG; The PRISMA Group. Preferred reporting items for systematic reviews and meta-analyses: The PRISMA Statement. PLoS Med. 2009;6(7):e1000097. doi: 10.1371/journal.pmed.1000097

10. Ministério da Saúde (BR). Programa Humanização do Parto: humanização no pré-natal e nascimento [Internet]. Brasília: Ministério da Saúde; 2002 [cited 2018 June 29]. Available from: http://bvsms.saude.gov.br/bvs/publicacoes/parto.pdf

11. Larkin P, Begley CM, Devane D. Women's preferences for childbirth experiences in the Republic of Ireland: a mixed methods study. BMC Pregnancy Childbirth. 2017;17(1):19. doi: 10.1186/s12884-016-1196-1

12. Strapasson MR, Kologeski TK, Schneider V, Renosto JM. Skin to skin contact of the newborn with its mother in the perspective of the multiprofessional team. J Nurs UFPE [Internet]. 2017;11(1):94-101. doi: 10.5205/reuol.9978-88449-6-1101201712

13. Gupta JK, Sood A, Hofmeyr GJ, Vogel JP. Position in the second stage of labour for women without epidural anaesthesia. Cochrane Database Syst Rev. 2012 May 16;(5):CD002006. doi: 10.1002/14651858.CD002006.pub3

14. Happel-Parkins A, Azim KA. At pains to consent: a narrative inquiry into women's attempts of natural childbirth. Women Birth. 2016;29(4):310-20. doi: 10.1016/j.wombi.2015.11.004

15. Aune I, Torvik HM, Selboe S-T, Skogås A-K, Persen J, Dahlberg U. Promoting a normal birth and a positive birth experience: Norwegian women's perspectives. Midwifery. 2015;31(7):721-7. doi: 10.1016/j.midw.2015.03.016

16. Borem P, Ferreira JBB, Silva UJ, Valério Jr J, Orlanda CMB. Increasing the percentage of vaginal birth in the private sector in Brazil through the redesign of care model. Rev Bras Ginecol Obstet. 2015;37(10):446-54. doi: 10.1590/SO100-720320150005264

17. Côrtes CT, Santos RCS, Caroci AS, Oliveira SG, Oliveira SMJV, Riesco MLG. Implementation methodology of practices based on scientific evidence for assistance in natural delivery: a pilot study. Rev Esc Enferm USP. 2015;49(5):716-24. doi: 10.1590/S0080-623420150000500002

18. Coxon K, Sandall J, Fulop NJ. How do pregnancy and birth experiences influence planned place of birth in future pregnancies? Findings from a longitudinal, narrative study. Birth. 2015;42(2):141-8. doi: 10.1111/birt.12149

19. Hajian S, Shariati M, Mirzaii Najmabadi K, Yunesian M, Ajami MI. Use of the extended parallel process model (EPPM) to predict Iranian women's intention for vaginal delivery. J Transcult Nurs. 2015;26(3):234-43. doi: 10.1177/1043659614524247

20. Scarton J, Prates LA, Wilhelm LA, Silva SC, Possati AB, Ilha CB, et al. "It was worth it when I saw his face": experiences of primiparous women during natural childbirth. Rev Gaúcha Enferm. 2015;36(spe):143-51. doi: 10.1590/1983-1447.2015.esp.56786

21. Serçekuş P, Egelioglu Cetisli N, İnci FH. Birth preferences by nulliparous women and their partners in Turkey. Sex Reprod Healthc. 2015;6(3):182-5. doi: 10.1016/j.srhc.2015.03.002

22. Silva ALS, Nascimento ER, Coelho EAC. Nurses practices to promote dignity, participation and empowerment of women in natural childbirth. Esc Anna Nery. 2015;19(3):424-31. doi: 10.5935/1414-8145.20150056

23. Skogheim G, Hanssen TA. Midwives' experiences of labour care in midwifery units. A qualitative interview study in a Norwegian setting. Sex Reprod Healthc. 2015;6(4):230-5. doi: 10.1016/j.srhc.2015.05.001

24. Hammond A, Foureur M, Homer CSE. The hardware and software implications of hospital birth room design: a midwifery perspective. Midwifery. 2014;30(7):825-30. doi: 10.1016/j.midw.2013.07.013

25. Liu Y, Liu Y, Huang X, Du C, Peng J, Huang P, et al. A comparison of maternal and neonatal outcomes between water immersion during labor and conventional labor and delivery. BMC Pregnancy Childbirth. 2014;14:160. doi: 10.1186/1471-2393-14-160

26. Nutter E, Meyer S, Shaw-Battista J, Marowitz A. Waterbirth: an integrative analysis of peer-reviewed literature. J Midwifery Womens Health. 2014;59(3):286-319. doi: 10.1111/jmwh.12194

27. Jamas MT, Hoga LAK, Reberte LM. Women's narratives on care received in a birthing center. Cad Saúde Pública. 2013;29(12):2436-46. doi: 10.1590/0102-311X00039713 
28. Karlsdottir SI, Halldorsdottir S, Lundgren I. The third paradigm in labour pain preparation and management: the childbearing woman's paradigm. Scand J Caring Sci. 2013;28(2):315-27. doi: 10.1111/scs.12061

29. Lawrence A, Lewis L, Hofmeyr GJ, Styles C. Maternal positions and mobility during first stage labour. Cochrane Database Syst Rev. 2013;(2):CD003934. doi: 10.1002/14651858.CD003934.pub4

30. Simmonds AH, Peter E, Hodnett ED, McGillis Hall L. Understanding the moral nature of intrapartum nursing. J Obstet Gynecol Neonatal Nurs. 2013;42(2):148-56. doi: 10.1111/1552-6909.12016

31. Hodnett ED, Downe S, Walsh D. Alternative versus conventional institutional settings for birth. Cochrane Database Syst Rev. 2012;(8):CD000012. doi: 10.1002/14651858.CD000012.pub4

32. Cheung NF, Mander R, Wang X, Fu W, Zhou H, Zhang L. Clinical outcomes of the first midwife-led normal birth unit in China: a retrospective cohort study. Midwifery. 2011;27(5):582-7. doi: 10.1016/j.midw.2010.05.012

33. Cheung NF, Mander R, Wang X, Fu W, Zhou H, Zhang L. Views of Chinese women and health professionals about midwife-led care in China. Midwifery. 2011;27(6):842-7. doi: 10.1016/j.midw.2010.09.001

34. Mota e Silva L, Oliveira SMJV, Silva FMB, Alvarenga MB. Using the Swiss ball in labor. Acta Paul Enferm. 2011;24(5):656-62. doi: 10.1590/ S0103-21002011000500010

35. Liu YH, Chang MY, Chen CH. Effects of music therapy on labour pain and anxiety in Taiwanese first-time mothers. J Clin Nurs. 2010;19(78):1065-72. doi: 10.1111/j.1365-2702.2009.03028.x

36. Riesco MLG, Oliveira SMJV, Bonadio IC, Schneck CA, Silva FMB, Diniz CSG, et al. Birth centers in Brazil: scientific production review. Rev EsC Enferm USP. 2009;43(spe2):1291-6. doi: 10.1590/S0080-62342009000600026

37. Silva FMB, Oliveira SMJV, Nobre MRC. A randomised controlled trial evaluating the effect of immersion bath on labour pain. Midwifery. 2009;25(3):286-94. doi: 10.1016/j.midw.2007.04.006

38. Romano AM, Lothian JA. Promoting, protecting, and supporting normal birth: a look at the evidence. J Obstet Gynecol Neonatal Nurs. 2008;37(1):94-105. doi: 10.1111/j.1552-6909.2007.00210.x

39. Lundgren I, Berg M. Central concepts in the midwife-woman relationship. Scand J Caring Sci. 2007;21(2):220-8. doi: 10.1111/j.1471-6712.2007.00460.x

40. Walsh DJ. A birth centre's encounters with discourses of childbirth: how resistance led to innovation. Sociol Health IIIn. 2007;29(2):216-32. doi: 10.1111/j.1467-9566.2007.00545.x

41. Bio E, Bittar RE, Zugaib M. Influência da mobilidade materna na duração da fase ativa do trabalho de parto. Rev Bras Ginecol Obstet. 2006;28(11):671-9. doi: 10.1590/S0100-72032006001100007

42. Mousley S. Audit of an aromatherapy service in a maternity unit. Complement Ther Clin Pract. 2005;11(3):205-10. doi: 10.1016/j.ctcp.2004.10.005

43. Hoga LAK. Motivação de enfermeiras obstétricas para o desenvolvimento de seu trabalho em uma casa de parto. Rev Min Enferm [Internet]. 2004 [cited 2018 Jul 02];8(3):369-73. Available from: http://www.reme.org.br/artigo/detalhes/725

44. Yildirim G, Sahin NH. The effect of breathing and skin stimulation techniques on labour pain perception of Turkish women. Pain Res Manag. 2004;9(4):183-7. doi: 10.1155/2004/686913

45. Lauzon L, Hodnett E. Labour assessment programs to delay admission to labour wards. Cochrane Database Syst Rev. $2001 ;(3): C D 000936$. doi: 10.1002/14651858.CD000936

46. Azevedo LGF, Nascimento TF. As tecnologias não invasivas de enfermagem obstétrica no trabalho de parto e parto: um cuidado singular. In: Zveiter M, Pereira ALF, organizadores. Curso de aprimoramento para enfermeiras obstétricas, com enfoque no componente parto e nascimento da rede cegonha. Rio de Janeiro: Associação Brasileira de Obstetrizes e Enfermeiros Obstetras do Rio de Janeiro (Abenfo-RJ); 2014. p. 51-8.

47. Dias PF. Ambiência para o trabalho de parto e parto normal institucionalizado: identificação do conceito [Internet]. [Alfenas]; 2017[cited 2018 July 02]. Available from: https://bdtd.unifal-mg.edu.br:8443/bitstream/tede/917/5/Disserta\%C3\%A7\%C3\%A30\%20de\%20Paula\%20 Faria\%20Dias.pdf

48. Ribeiro JP, Gomes GC, Thofehrn MB. Health facility environment as humanization strategy care in the pediatric unit: systematic review. Rev Esc Enferm USP. 2014;48(3):527-36. doi: 10.1590/S0080-623420140000300020

49. Buriola AA, Pinho LB, Kantorski LP, Matsuda LM. Assessment of the physical and human resource structure of a psychiatric emergency service. Texto Contexto Enferm. 2017;26(4):e3240016. doi: 10.1590/0104-07072017003240016 